To Cite: Karakus A, Ceylan H, Erdogan O, 2022. Cloning and Expression of Rat Brain Acetylcholinesterase Enzyme in Escherichia coli. Journal of the Institute of Science and Technology, 12(1): 287-296.

\title{
Cloning and Expression of Rat Brain Acetylcholinesterase Enzyme in Escherichia coli
}

\section{Ahmet KARAKUS ${ }^{1}$, Hamid CEYLAN ${ }^{2}$, Orhan ERDOGAN ${ }^{2 *}$}

ÖZET: In this study, the gene region of rat (Rattus norvegicus) brain acetylcholinesterase enzyme was amplified in PCR with designed forward and reverse primers and it was ligated into a pET-SUMO vector under suitable conditions. This recombinant vector was transformed to competent Escherichia coli cells and it was grown in liquid LB medium including kanamycin. Colony PCR was performed from growing colony and PCR products were checked with agarose gel electrophoresis. The correct colonies were grown in a liquid medium for plasmid isolation. After plasmid isolation, these recombinant constructs were used for whether the gene inserts properly with cross-PCR. After determining the accuracy of the plasmid, recombinant vectors were transferred into the E. coli BL21 (DE3) cells to perform protein production. Cells were grown in IPTG induced larger media for hours. Enzyme activity and SDS-PAGE analysis were performed from homogenate for each treatment samples.

Keywords: Rattus norvegicus, Acetylcholinesterase, Cloning, pET-SUMO vector, E. Coli

\footnotetext{
${ }^{1}$ Ahmet KARAKUS (Orcid ID: 0000-0003-1458-808X), Bartin University, Science Faculty, Department of Biotechnology, Bartin, Turkiye

${ }^{2}$ Hamid CEYLAN (Orcid ID: 0000-0003-3781-4406), Orhan ERDOĞAN (Orcid ID: 0000-0001-8908-7293), Ataturk University, Science Faculty, Department of Molecular Biology and Genetics, Erzurum, Turkiye

*Sorumlu Yazar/Corresponding Author: Orhan ERDOGAN, e-mail: oerdogan@atauni.edu.tr

This study was produced from Ahmet KARAKUŞ's Master's thesis. The article was presented as a poster at the "International Eurasia Pharmacy Congress" in Erzincan on 3-7 September 2015.
} 


\section{INTRODUCTION}

Acetylcholine is an ester with important biological effects. The strong pharmacological effect of acetylcholine was determined in 1906 (Nachmansohhn 1952). Acetylcholine, whose effects on heart tissue were revealed for the first time by Henry Hallett Dale in 1914, is a neuromodulator that plays a role in the central and peripheral nervous system. Choline is synthesized from acetyl CoA and choline by the enzyme acetyltransferase. The enzyme acetylcholinesterase (AChE), which is abundant in the synaptic space, breaks down free acetylcholine into choline and acetate metabolites (Nirogi et al. 2010).

Acetylcholinesterase hydrolyzes acetylcholine, a neurotransmitter in cholinergic synapses. Acetylcholine released into the synaptic space binds to its receptors in the postsynaptic membrane (Lester 1977). AChE in the same region terminates signal transmission by hydrolyzing acetylcholine (Whittaker 1990). AChE with very high catalytic activity breaks down 25,000 acetylcholine molecules per second (Quinn 1987). The released choline is taken up again by the presynaptic nerve. Choline combines with acetyl CoA catalyzed by cholineacetyltransferase to form acetylcholine again (Kim et al. 2006).

Hydrolysis of acetylcholine is regulated by cholinesterase inhibitors. There are two types of cholinesterase enzymes. These include acetylcholinesterase and butyrylcholinesterase. Substances that inhibit the enzyme acetylcholinesterase are defined as cholinesterase inhibitors or anticholinesterases (Colovic et al. 2013). Cholinesterase inhibitors that inhibit hydrolysis of acetylcholinesterase enzyme contribute to central and peripheral cholinergic function and strengthen this function (Alaşehirli 2005).

Since pathogenesis and pathophysiology of Alzheimer's disease can not be fully clarified, there is no adequate and complete preventive treatment for today (Golde 2003). Acetylcholinesterase inhibitors (AChEI) are the most effective treatment agents proven (McGleenon et al. 1999). AChEIs prevent the destruction of acetylcholine by cholinesterase and increase the amount of acetylcholine in neuronal synapse and prolong the biochemical and functional effect of acetylcholine in the brain (Snowdon et al. 1997).

In this study; In this study, rat AChE gene was cloned into pET-SUMO vector and acetylcholinesterase enzyme, a product of this gene, was produced recombinantly in E. coli cells and the activity and molecular weight of the produced enzyme were determined.. In the following stages, it is thought that AChE enzyme purification and characterization can be carried out to prevent drug studies.

\section{MATERIALS AND METHODS}

\section{Total RNA Isolation and cDNA Production}

Total RNA was isolated rat brain by using Méndez's method (Méndez et al. 2011). The obtained products were checked by agarose gel electrophoresis and NanoDrop. cDNA library was performed according to the reverse transcriptase method. For this process, First-Strand cDNA Synthesis Kit (Invitrogen, USA) and Oligodt primers were used.

\section{Plasmid construction and cloning of $\mathrm{AChE}$}

For recombinant production of AChE protein, the coding sequence of rat AChE (NM_172009) was cloned into the vector (pET-SUMO). The rat AChE gene sequence (NM_172009) was amplified with designed forward and reverse primer with PCR, sequence information of the primers is given in Table 1. Afterwards, AChE gene was amplified by applying the PCR parameters given in Table 2. PCR products were checked by agarose gel electrophoresis and PCR product was purified from agarose gel. This sequence was cloned into the pET-SUMO vector (Figure 1). 
Table 1. Primer sequences used in amplification of the rat AChE gene sequence.

\begin{tabular}{cc}
\hline Primer & $5^{\prime}-3^{\prime}$ \\
\hline Forward & ATGAGGCCTCCCTGGTATCC \\
\hline Reverse & TCACAGGTCTGAGCAGCGT \\
\hline
\end{tabular}

Table 2. PCR parameters applied in amplification of AChE gene

\begin{tabular}{cc}
\hline Steps & Temperature $\left({ }^{\circ} \mathrm{C}\right) /$ Time / Cycle \\
\hline Pre-denaturation & $94 / 4 \mathrm{~min} / 1$ \\
\hline Denaturation & $94 / 90 \mathrm{~s} / 30$ \\
\hline Annealing & $60 / 40 \mathrm{~s} / 30$ \\
\hline Extension & $72 / 100 \mathrm{~s} / 30$ \\
\hline Final extension & $72 / 10 \mathrm{~min} / 1$ \\
\hline End of the reaction & $4 /-/-$ \\
\hline
\end{tabular}

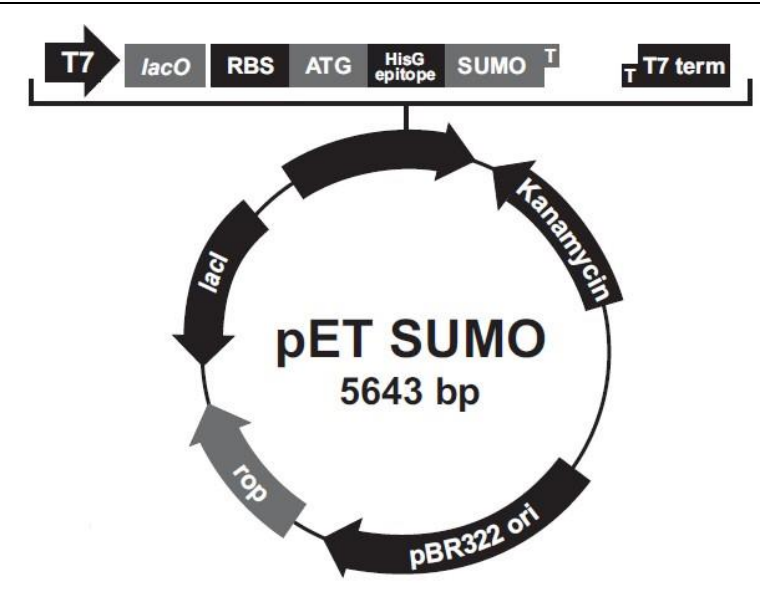

Figure 1. pET-SUMO vector map

\section{Recombinant protein expression}

Obtained recombinant vector was transformed to component $E$. coli One Shot Mach-T $1^{\mathrm{R}}$ cells and it was incubated for 1 night at $37^{\circ} \mathrm{C}$ in $\mathrm{LB}$ medium ( $1 \%$ tryptone, $0.5 \% \mathrm{NaCl}, 2 \%$ agar and $0.5 \%$ yeast) containing $50 \mu \mathrm{g} / \mathrm{mL}$ kanamycin. Colony PCR was performed to determine the colonies carrying the recombinant vector. Four combinations of vector-specific and gene-specific primers (gene-gene, vectorvector, gene forward-vector reverse, and gene reverse-vector forward) were used to determine whether the vector was an insert. Plasmid isolation was performed.

Isolated plasmids were transferred to $E$. coli BL21(DE3) cells and grown in LB plates to perform protein production. Transfer procedure was performed by classical heat shock method. A single colony was taken from the agar plate and inoculated in $10 \mathrm{~mL}$ of $\mathrm{LB}$ medium and left in an incubator at $37^{\circ} \mathrm{C}$ and $200 \mathrm{rpm}$ for 1 night to prepare the preculture.

To obtain the recombinant protein, $1 \mathrm{~mL}$ of preculture was added to $200 \mathrm{~mL}$ of $50 \mu \mathrm{g} / \mathrm{mL}$ antibiotic and $1 \%$ glucose including LB medium. When OD600 $=0.6$ measured in the spectrophotometer, IPTG was added to the medium and incubated at $200 \mathrm{rpm}$ and $37^{\circ} \mathrm{C}$.

\section{Protein purification and pilot expression of $\mathrm{AChE}$}

After IPTG induction, cells were centrifuged at $3000 \mathrm{rpm}$ for 5 minutes to determine whether protein was produced. Cell pellets were resuspended in $1 \mathrm{~mL}$ of lysis buffer. Next, the cells was sonicated and lysed by a freeze-thaw cycle ( 3 times) with liquid nitrogen $\left(-196^{\circ} \mathrm{C}\right)$ and a $42^{\circ} \mathrm{C}$ water bath. Then 
the cell lysate was centrifuged at $10.000 \mathrm{rpm}$ for $1 \mathrm{~min}$. The supernatant was taken into a new tube and stored at $-20^{\circ} \mathrm{C}$.

Produced Rat AChE protein concentration was detected by the Bradford method (Bradford 1976) using Bovine Serum Albumin (BSA). The absorbance was measured in the spectrophotometer at 595 nm. AChE enzyme activity was determined by Ellman's method (Ellman et al., 1961). Time dependent expression level (0-7 s) and molecular weight of the produced recombinant protein were analysed by SDS-PAGE (12\%) method.

\section{RESULTS AND DISCUSSION}

\section{Qualitative Determination of Isolated RNA by Agarose Gel Electrophoresis and cDNA Library}

Total RNA isolation from rat brain tissue was performed according to the manufacturer's protocol and qualitatively determined by agarose gel electrophoresis (Figure 2) and rat cDNA library was performed (Figure 3).

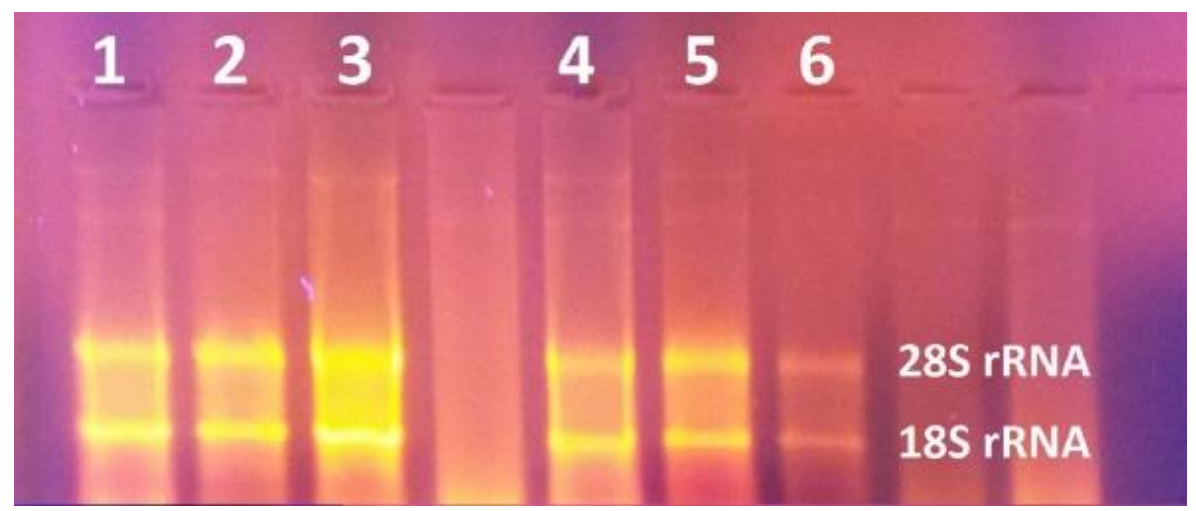

Figure 2. Gel image of total RNA from rat brain tissue $(1,2,3,4,5$, 6 gel RNA samples loaded with $18 \mathrm{~S}$ and 28S rRNA bands)

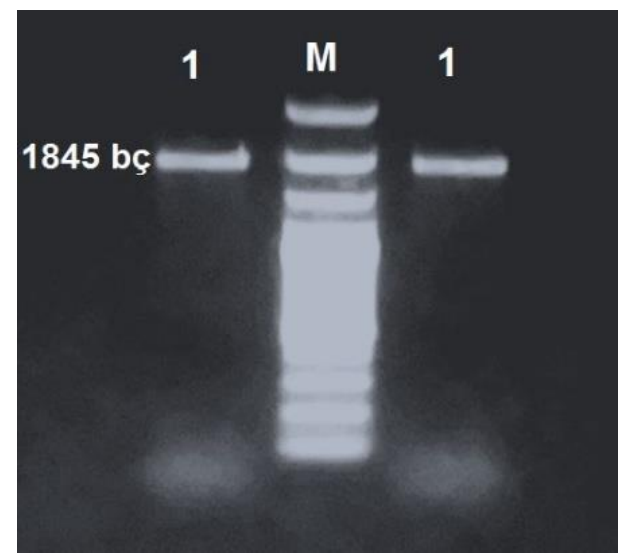

Figure 3. The gene region obtained by PCR from the cDNA library. (1: PCR sample loaded on gel, M: Marker)

\section{Cloning of ACHE into pET-SUMO vector}

The rat AChE sequence was ligated and cloned into the pET-SUMO vector. Correct placement of the gene in the pET-SUMO vector was confirmed by colony and cross PCR (Figure 3, Figure 4 and Figure 5). 
Cloning and Expression of Rat Brain Acetylcholinesterase Enzyme in Escherichia coli

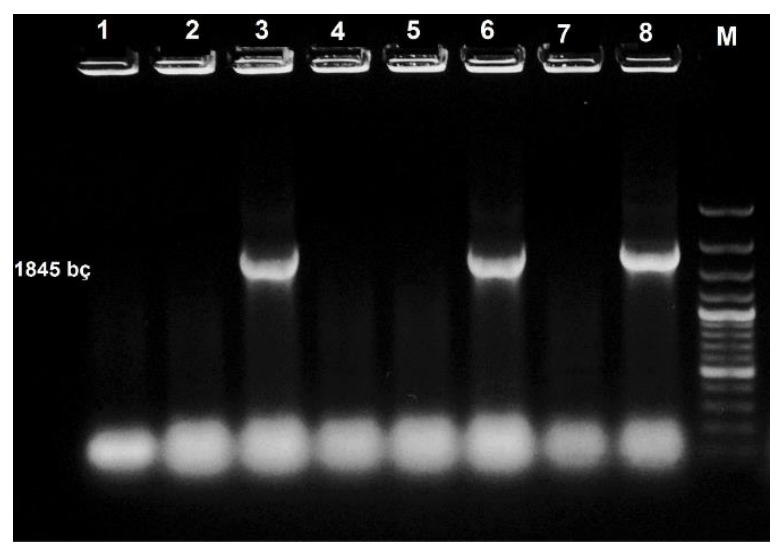

Figure 3. Gel image of bands obtained from colony PCR with primer of target gene. (M: Marker, 1, 2, 3, 4, 5, 6, 7, 8: Colonies enumerated for PCR, 3rd, 6th and 8th colonies were evaluated as positive because they gave bands in the $1845 \mathrm{bp}$ )

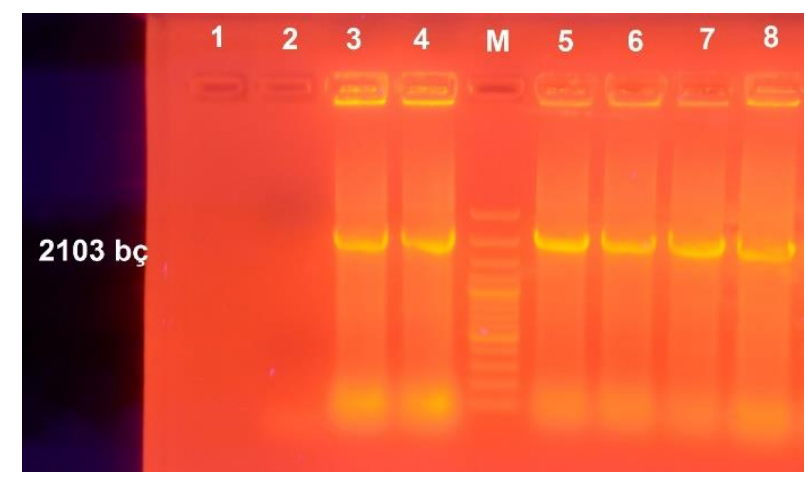

Figure 4. Gel image of bands obtained by colony PCR with vector primer. (M: Marker, 1, 2, 3, 4, 5, 6, 7, 8: Numbered colonies for PCR, 3rd, 4th, 5th, 6th and 8th colonies were positive because they gave band in 2103 bp region. we evaluated)

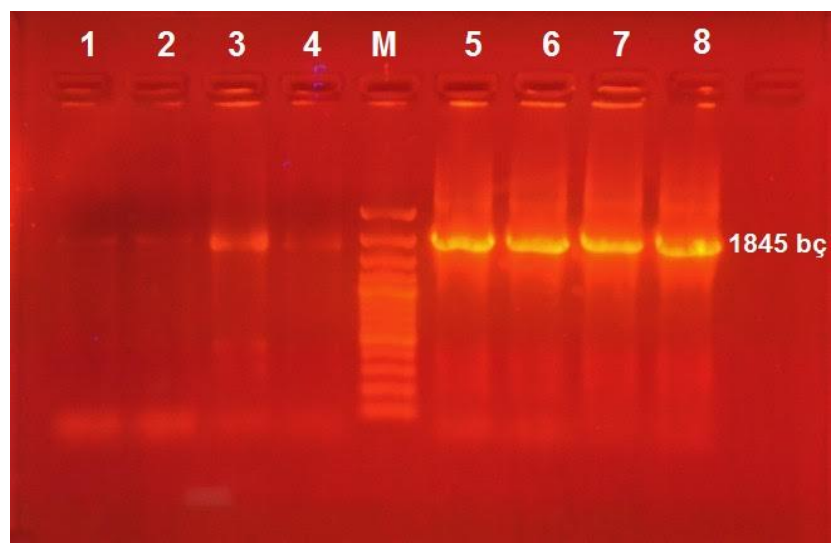

Figure 5. Gel image obtained by cross-PCR from plasmid

\section{Pilot expression of AChE}

The protein quainty of the samples taken from the samples induced by IPTG at the 1st, 2nd, 4th, 6th and 7th hours are indicated in Table 3. Accordingly, samples induced with IPTG at 6 and 7 hours were determined to contain approximately 2.7 fold more protein than samples not induced by IPTG. Then cells were harvested and cell lysate was detected by SDSPAGE. With SDS-PAGE analysis, the presence of approximately $80 \mathrm{kDA}$ of product was detected in the gel. (Figure 6). 
Cloning and Expression of Rat Brain Acetylcholinesterase Enzyme in Escherichia coli

Table 3. Activity measurement results of acetylcholinesterase enzyme

\begin{tabular}{ccc}
\hline $\begin{array}{c}\text { Time of Samples } \\
(\mathrm{h})\end{array}$ & $\begin{array}{c}\text { IPTG }+ \\
\text { (unit) }\end{array}$ & $\begin{array}{c}\text { IPTG }- \\
\text { (unit) }\end{array}$ \\
\hline 0 & 16 & 12 \\
\hline 2 & 27 & 16 \\
\hline 4 & 44 & 22 \\
\hline 6 & 72 & 26 \\
\hline 7 & 68 & 24 \\
\hline
\end{tabular}

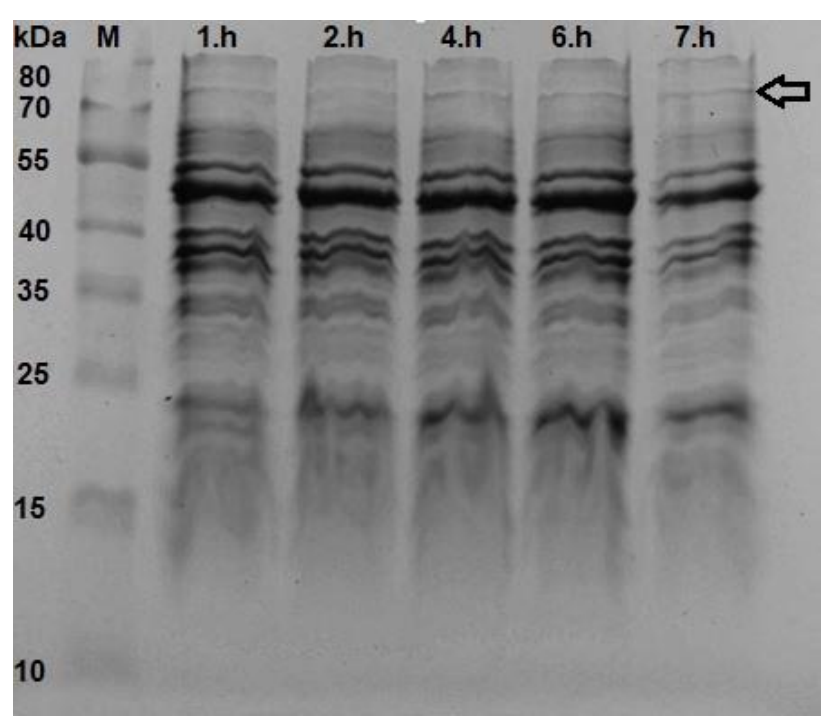

Figure 6. SDS-PAGE analysis of cell homogenate obtained after lysis (M: Marker, kDa: Kilodalton, 1.h, 2.h, 4.h, 6.h, 7.h: When samples were taken)

In this study, it was aimed to clone acetylcholinesterase (AChE) enzyme from rat brain tissue and express it using a prokaryotic host. In this context, the region encoding the enzyme was isolated from the cDNA library of the relevant tissue using specific primers. The resulting gene region was transferred to a vector for cloning purposes. This recombinant vector was then transferred to a suitable expression host to produce the enzyme.

AChE plays a biological role in neurotransmission at synapses at the cholinergic junction by rapidly hydrolyzing its substrate acetylcholine to acetate and choline (Soreq and Seidman, 2001). In addition, non-cholinergic roles of cholinesterase such as cell adhesion, neurite outgrowth, and apoptosis have been reported in vertebrates and invertebrates (Park et al., 2004; Zhang and Greenberg, 2012; He et al., 2012; Lu et al.,2012).

Acetylcholinesterase enzyme was obtained recombinantly from different species such as human (Velan et al. 1991), rat (Legay et al. 1993; Coussen et al. 1995) and mouse (Vellom et al. 1993) for different purposes. The main objectives of the studies are structural analysis (Kronman et al. 1992), posttranslational arrangements that occur during the maturation of the protein (Coussen et al. 1995), and the explanation of the substrate relationship of AChE, which is different from other cholinesterases (Vellom et al. 1993). It was on the clarification of tasks and their reasons. In these studies, the enzyme was successfully produced in many different hosts, from mammalian cell lines (Lazar et al. 1993) to plants (Yamamoto et al. 2009).

Recombinant therapeutics can be obtained using microbial systems, animal and plant hosts. Microbial systems are one step ahead at this point compared to other intermediaries, as they have the capacity to produce fast and high-yield products in addition to their low cost table. In addition, the 
microbial systems do not have a contagious viral concern and are accepted by the authorities as the most suitable hosts recommended for this purpose (Picanco-Castro et al. 2013).

SUMO proteins, like ubiquitins, are synthesized in a precursor form before being conjugated to the target protein. The main difference between these two groups is that while ubiquitins are targeted to a protein for its degradation, cellular processes such as nuclear transport, transcriptional regulation and protein stability occur on the SUMO-targeted protein (Boggio et al. 2004). Producing efficient and soluble recombinant protein, especially in low-level hosts such as E. coli, is one of the most important problems encountered (Wang et al. 2010). To overcome this problem, approaches such as the use of fusion proteins, promoter alteration and chaperone co-expression are preferred (Thomas and Baneyx 1997; Zhang et al. 1998).

Fusion proteins not only ensure the expression and proper folding of the target protein, but also protect the related protein from degradation, facilitate purification and detection. For this reason, it has started to be preferred quite frequently in recombinant production techniques. The most commonly used fusion proteins are maltosebinding protein (MBP) (Pryor and Leiting 1997), NUS A (De Marco et al. 2004), glutathione S-transferase (GST), ubiquitin (Ub), thioredoxin (TRX) (LaVallie et al. . 1993) and SUMO (Catanzariti et al. 2004).

Some recent studies have shown that acetylcholinesterase may be a marker and regulator for apoptosis (Park et al. 2004; Ye et al. 2015). Therefore, conclusions can be drawn that AChE may be a promising tumor suppressor ( $\mathrm{Lu}$ et al. 2013).

Neurodegenerative diseases are a type of neurological diseases, and they generally manifest themselves with the loss of function of neurons over time and ultimately the death of the cell. Today, the causes and pathological mechanisms of the formation of these diseases have not yet been fully explained (Lu et al. 2013). Many neurodegenerative diseases are characterized by disturbances in the cholinergic system. For this reason, inhibition of cholinergic system components or keeping the amount of molecules targeted by these components at an optimum level is seen as the most common and most likely approach for the treatment of related diseases (Holzgrabe et al. 2007). However, since these types of diseases are generally progressive, current treatment strategies can only slow down the progression seen in the pathogenesis of the disease (Dorronsoro et al. 2003).

The acetylcholinesterase enzyme is a very sensitive enzyme that can lose its activity quickly. With the help of manipulative techniques such as directed mutation generation methods, it is possible to produce more useful products both in the industrial and therapeutic fields, which can maintain the initial activity for a longer time by increasing the stability of the enzyme with the changes made on the active site.

It has been proven in the literature that bacterial production systems are very suitable models for the production of recombinant products. However, the biggest disadvantage of these systems is that they cannot produce after a certain point because the growth medium is not sufficient after a certain level. Today, specialized systems called bioreactor/fermentor are used, especially for microbial models. With the mentioned systems, the production of microbial biomass, enzymes, metabolites and recombinant products can be done on larger scales. Considering that the amount of product and productivity are obtained from a very small volume in our study, it is thought that better results can be obtained when the production is done by using this type of intermediaries. 


\section{CONCLUSION}

In summary, Rattus norvegicus AChE gene cloning and expression have been performed, which is of extremly importance to enable further studies on the characterization of AChE enzyme. Today, developing technology allows the design and construction of novel proteins by modification of the amino acid sequence in vitro using recombinant DNA technology. In this way, it is thought that research can be done about how mutations can be made in vitro in the active part of AChE enzyme and how enzyme activity can change. Whereby about the molecular structure of AChE enzyme shown as targets for drug design and function can be made more extensive information. We believe that obtaining this data may allow the design of selective inhibitors against this enzyme, which has an important place in the cholinergic junction.

\section{ACKNOWLEDGEMENTS}

This study was supported by Ataturk University Scientific Research Projects Coordination Office (Project ID: 2012/172).

\section{Conflict of Interest}

The article authors declare that there is no conflict of interest between them.

\section{Author's Contributions}

The authors declare that they have contributed equally to the article.

\section{REFERENCES}

Alaşehirli B, 2005, The Inhibitors Of Cholinesterase (Anticholinesterases). Journal of Internal Medical Sciences Pharmacology, 1 (18): 47.

Bradford MM, 1976. A rapid and sensitive method for the quantitation of microgram quantities of protein utilizing the principle of protein-dye binding. Analytical Biochemistry, 72: 248-254.

Boggio R, Colombo R, Hay RT, Draetta GF, Chiocca S, 2004. A mechanism for inhibiting the SUMO pathway. Molecular Cell, 16 (4): 549-561.

Catanzariti AM, Soboleva TA, Jans DA, Board PG, Baker RT, 2004. An efficient system for high-level expression and easy purification of authentic recombinant proteins. Protein Science, 13 (5): 1331-1339.

Colovic MB, Krstic DZ, Lazarevic-Pasti TD, Bondzic AM, Vasic VM, 2013. Acetylcholinesterase inhibitors: pharmacology and toxicology. Current Neuropharmacology, 11 (3): 315-335.

Coussen F, Bonnerot C, Massoulie J, 1995. Stable expression of acetylcholinesterase and associated collagenic subunits in transfected RBL cell lines: production of GPI-anchored dimers and collagen-tailed forms. European Journal of Cell Biology, 67 (3): 254-260.

De Marco V, Stier G, Blandin S, De Marco A, 2004. The solubility and stability of recombinant proteins are increased by their fusion to NusA. Biochemical and Biophysical Research Communications, 322 (3): 766771.

Dorronsoro I, Castro A, Martinez, A, 2003. Peripheral and dual binding site inhibitors of acetylcholinesterase as neurodegenerative disease modifying agents. Expert Opinion on Therapeutic Patents, 13 (11): 1725-1732.

Ellman GL, Courtney KD, Andres Jr V, Featherstone RM, 1961. A new and rapid colorimetric determination of acetylcholinesterase activity. Biochemical Pharmacology, 7 (2): 88-95.

Golde TE, 2003. Alzheimer disease therapy: can the amyloid cascade be halted? The Journal of Clinical Investigation, 111 (1): 11-18.

Greig NH, Lahiri DK, Sambamurti K, 2002. Butyrylcholinesterase: an important new target in Alzheimer's disease therapy. International Psychogeriatrics, 14 (1): 77-91.

He G, Sun Y, Li F, 2012. RNA interference of two acetylcholinesterase genes in Plutella xylostella reveals their different functions. Archives of Insect Biochemistry and Physiology, 79 (2): 75-86. 
Holzgrabe U, Kapkova P Alptuzun, V, Scheiber J, Kugelmann E, 2007. Targeting acetylcholinesterase to treat neurodegeneration. Expert Opinion on Therapeutic Targets, 11 (2): 161-179.

Kim AR, Rylett RJ, Shilton BH. Substrate binding and catalytic mechanism of human choline acetyltransferase. Biochemistry. 2006 Dec 12;45(49):14621-31.Kronman C, Velan B, Gozes Y, Leitner M, Flashner Y, Lazar A, Marcus D, Sery T, Papier Y, Grosfeld H, 1992. Production and secretion of high levels of recombinant human acetylcholinesterase in cultured cell lines: microheterogeneity of the catalytic subunit. Gene, 121 (2): 295-304.

LaVallie ER, DiBlasio EA, Kovacic S, Grant KL, Schendel PF, McCoy JM, 1993. A thioredoxin gene fusion expression system that circumvents inclusion body formation in the E. coli cytoplasm. Biotechnology, 11: 187-193.

Lazar A, Reuveny S, Kronman C, Velan B, Shafferman A, 1993. Evaluation of anchorage-dependent cell propagation systems for production of human acetylcholinesterase by recombinant 293 cells. Cytotechnolog, 13 (2): 115-123.

Legay C, Bon S, Vernier P, Coussen F, Massoulie J, 1993. Cloning and expression of a rat acetylcholinesterase subunit: generation of multiple molecular forms and complementarity with a Torpedo collagenic subunit. Journal of Neurochemistry, 60 (1): 337-346.

Lester HA, 1977. The response to acetylcholine. Scientific American, 236 (2): 106-120.

Lu W, Jiang J, Yang G, Lai J, Lu K, 2012. Endovascular treatment for the spontaneous rupture of a nonaneurysmal subdiaphragmatic aorta. Vasa, 41 (4): 288-291.

Lu H, Liu X, Deng Y, Qing H, 2013. DNA methylation, a hand behind neurodegenerative diseases. Frontiers in Aging Neuroscience, 5: 85.

Massoulie J, Pezzementi L, Bon S, Krejci E, Vallette FM, 1993. Molecular and cellular biology of cholinesterases. Progress in Neurobiology, 41 (1): 31-91.

McGleenon B, Dynan K, Passmore A, 1999. Acetylcholinesterase inhibitors in Alzheimer's disease. British Journal of Clinical Pharmacology, 48 (4): 471.

Méndez V, Avelar E, Morales A, Cervantes M, Araiza A, González D, 2011. A rapid protocol for purification of total RNA for tissues collected from pigs at a slaughterhouse. Genetics and Molecular Research: GMR, 10 (4): 3251-3255.

Mesulam MM, Guillozet A, Shaw P, Levey A, Duysen E, Lockridge O, 2002. Acetylcholinesterase knockouts establish central cholinergic pathways and can use butyrylcholinesterase to hydrolyze acetylcholine. Neuroscience, 110 (4): 627-639.

Nachmansohhn, D., 1952. In Modern Trens in Physicology, Biochemistry. Academic Press, New York, 229.

Nirogi R, Mudigonda K, Kandikere V, Ponnamaneni R, 2010. Quantification of acetylcholine, an essential neurotransmitter, in brain microdialysis samples by liquid chromatography mass spectrometry. Biomedical Chromatography, 24 (1): 39-48.

Park SE, Kim ND, Yoo YH, 2004. Acetylcholinesterase plays a pivotal role in apoptosome formation. Cancer Research, 64 (24): 9230.

Picanco-Castro V, Biaggio RT, Cova DT, Swiech K, 2013. Production of recombinant therapeutic proteins in human cells: current achievements and future perspectives. Protein \& Peptide Letters, 20 (12): 1373-1381.

Quinn DM, 1987. Acetylcholinesterase: enzyme structure, reaction dynamics, and virtual transition states. Chemical Reviews, 87 (5): 955-979.

Snowdon DA, Greiner LH, Mortimer JA, Riley KP, Greiner PA, Markesbery WR, 1997. Brain infarction and the clinical expression of Alzheimer disease. The Nun Study. Jama, 277 (10): 813-817.

Soreq H, and Seidman S, 2001. Acetylcholinesterase new roles for an old actor. Nature Reviews Neuroscience, 2 (4): 294-302.

Thomas JG, Baneyx F, 1997. Divergent Effects of Chaperone Overexpression and Ethanol Supplementation on Inclusion Body Formation in Recombinant Escherichia coli. Protein Expression and Purification, 11 (3): 289-296. 
Velan B, Grosfeld H, Kronman C, Leitner M, Gozes Y, Lazar A, Flashner Y, Marcus D, Cohen S, Shafferman A, 1991. The effect of elimination of intersubunit disulfide bonds on the activity, assembly, and secretion of recombinant human acetylcholinesterase. Expression of acetylcholinesterase Cys-580-Ala mutant. Journal of Biological Chemistry, 266 (35): 23977-23984.

Vellom DC, Radic Z, Li Y, Pickering NA, Camp S, Taylor, P, 1993. Amino acid residues controlling acetylcholinesterase and butyrylcholinesterase specificity. Biochemistry, 32 (1): 12-17.

Wang Z, Li H, Guan W, Ling H, Wang Z, Mu T, Shuler FD, Fang X, 2010. Human SUMO fusion systems enhance protein expression and solubility. Protein Expression and Purification, 73 (2): 203-208.

Whittaker VP, 1990. The contribution of drugs and toxins to understanding of cholinergic function. Trends in Pharmacological Sciences, 11 (1): 8-13.

Yamamoto K, Oguri S, Chiba S, Momonoki YS, 2009. Molecular cloning of acetylcholinesterase gene from Salicornia europaea L. Plant Signaling and Behavior, 4 (5): 361-366.

Ye X, Zhang C, Chen Y, Zhou T, 2015. Upregulation of Acetylcholinesterase Mediated by p53 Contributes to Cisplatin-Induced Apoptosis in Human Breast Cancer Cell. Journal of Cancer, 6 (1): 48-53.

Zhang Y. Olsen DR, Nguyen KB, Olson PS, Rhodes ET, Mascarenhas D, 1998. Expression of eukaryotic proteins in soluble form in Escherichia coli. Protein Expression and Purification, 12 (2): 159-165.

Zhang XJ, and Greenberg DS, 2012. Acetylcholinesterase involvement in apoptosis. Frontiers in Molecular Neuroscience, 10 (5): 40. 